
survey. Horticultura Brasileira 39: 425-431. DOI: http://dx.doi.org/10.1590/s0102-0536-20210412

\title{
Firmness and biochemical composition of Shitake and Shimeji commercialized in natura and consumers' opinion survey
}

\author{
Pamela dos S Antunes ${ }^{1} \mathbb{D}$; Lígia Erpen-Dalla Corte ${ }^{1} \mathbb{D}$; Janaina CM Bueno ${ }^{2} \mathbb{D}$; Wilma Aparecida Spinosa ${ }^{1} \mathbb{D}$; \\ Juliano Tadeu V Resende ${ }^{1} \mathbb{D}$; Fernando T Hata ${ }^{1} \mathbb{D}$; Lilian C Cabrera ${ }^{3} \mathbb{D}$; Douglas M Zeffa ${ }^{4} \mathbb{D}$; Leandro SA \\ Gonçalves ${ }^{1} \mathbb{D}$; Leonel Vinícius Constantino ${ }^{1 \mathbb{D}}$
}

${ }^{1}$ Universidade Estadual de Londrina (UEL), Centro de Ciências Agrárias, Londrina-PR, Brasil; pamella.antunees@gmail.com; ligiacorte@uel. br; wilma.spinosa@uel.br; jvresende@uel.br; leandrosag@uel.br; leonel@uel.br; ${ }^{2}$ Universidade Estadual do Centro-Oeste(UNICENTRO), Pós-graduação em Agronomia, Guarapuava-PR, Brasil; janainametinoski@gmail.com; ${ }^{3}$ Universidade Estadual de Londrina (UEL), Centro de Estudos Sociais Aplicados, Londrina-PR, Brasil; liliancabrera_86@yahoo.com.br; ${ }^{4}$ Universidade Estadual de Maringá (UEM), Pósgraduação em Genética e Melhoramento, Maringá-PR, Brasil; douglas.mz@hotmail.com

\begin{abstract}
Mushroom production has been growing in Brazil due to the culinary versatility of this food and its high nutritional value. However, few studies associating the aspects of its quality with the profile and preference of its consumers can be found in literature. Thus, in this study, we aimed to evaluate the firmness and biochemical composition of Shimeji and Shitake, as well as, the consumers' profile and preference for purchasing these mushrooms. The mushrooms were characterized by firmness, protein and lipid content, total phenolic compounds, total flavonoids and antioxidation activity. In addition we carried out a survey on opinion of 308 mushroom consumers. The two mushrooms contain high protein content and low lipid content, and also expressive concentrations of bioactive compounds and antioxidant activity, suitable for these demanding functional food consumers. Shitake is approximately 4 times firmer than Shimeji and the highest levels for all analyzed biochemical attributes did not differ between the two studied mushrooms, except for protein content. The opinion survey indicated that young and adult women consume more mushrooms than men. Most of them buy mushrooms in supermarkets, and they are mostly higher educated people. No significant higher consumer preference for one of the two mushrooms analyzed was verified; however, most participants reported that they prioritize mushrooms which have characteristic aroma and flavor, smooth and juicy texture, being a convenient ingredient for a quick-cooking meal.
\end{abstract}

Keywords: Lentinula edodes, Pleurotus ostreatus, edible mushrooms, firmness, fungiculture, sensory analysis.

\section{RESUMO}

Firmeza e composição bioquímica de Shitake e Shimeji comercializados in natura e pesquisa de opinião com consumidores

A produção de cogumelos vem crescendo no Brasil, devido à versatilidade culinária desse alimento e alto valor nutricional. Ainda são escassos estudos que associam os aspectos de sua qualidade com o perfil e preferência dos seus consumidores. Assim, nesse trabalho foi comparada a firmeza e composição bioquímica de Shimeji e Shitake, e verificado o perfil e a preferência dos consumidores para compra. Os cogumelos foram caraterizados pela firmeza, teores de proteínas, lipídios, compostos fenólicos totais, flavonoides totais e atividade antioxidade, além da realização de pesquisa de opinião com 308 consumidores de cogumelos. Os dois cogumelos contêm alto teor de proteínas e baixo de lipídios, além de concentrações expressivas de compostos bioativos e de atividade antioxidante, desejáveis aos consumidores exigentes em alimentos funcionais. O Shitake é aproximadamente 4 vezes mais firme quer o Shimeji e os maiores teores para todos os atributos bioquímicos analisados não diferiram entre os dois cogumelos, exceto para o teor de proteínas. A pesquisa de opinião indicou que mulheres jovens e adultas consomem mais cogumelos que os homens. A maioria deles adquire os cogumelos em supermercados, e são pessoas com escolaridade, majoritariamente, de nível superior. Não foi constatada significativa maior preferência dos consumidores por um dos dois cogumelos analisados, mas a maioria dos participantes relataram que na compra priorizam cogumelos com aroma e sabor característicos, textura macia e suculenta, e que permita rapidez no preparo de refeições.

Palavras-chave: Lentinula edodes, Pleurotus ostreatus, cogumelos comestíveis, firmeza, fungicultura, análise sensorial.

Received on February 22, 2021; accepted on October 6, 2021

E dible mushroom market has grown significantly in recent years, due to an increasing demand for high nutritional value foods. Moreover, we highlight the Asian influence in
Brazilian cuisine, due to an increasing number of vegan people, since these mushrooms are considered an excellent source of protein, alternative to those of animal origin.
Mushrooms have been used in human diet for many years. They have a high content of protein and fiber, low content of fat, around $2 \%$ to $6 \%$, vitamins $\mathrm{A}$, $\mathrm{K}$ and $\mathrm{B}$ and minerals like potassium, 
calcium and iron (Valverde et al., 2014; Chun et al., 2020). Mushrooms also have antimicrobial activities (Alves et al., 2012), anticancer activities (Finimundy et al., 2013), compounds that protect against inflammatory processes ( $\mathrm{Yu}$ et $a l ., 2009)$ and cardiovascular diseases (Rahman et al., 2018).

Mushroom production has grown worldwide. In 2013, per capita consumption exceeded in $4.7 \mathrm{~kg}$ per year, representing more than 30 times since 1978 (Royse et al., 2017). The possibility of reusing agro-industrial waste as a substrate is another factor which contributes to the increase in mushroom production (Paula et al., 2001).

In Brazil, most of the production is carried out by small and medium family farming producers (Cabrera et al., 2020), which represent $80 \%$ of producers and provide about 12 thousand tons of mushrooms per year to the market (APTA, 2019). Most consumers are high-income people (Boin \& Nunes, 2018).

The most commonly-consumed edible mushrooms are Champignon de Paris (Agaricus bisporus), canned form, followed by Shimeji (Pleurotus ostreatus) and Shitake (Lentinula edodes), both in natura (ANPC, 2019), whose aroma, flavor and texture stood out, comparing to their dehydrated and canned forms.

In spite of the fact that some studies addressing the biochemical composition of mushrooms can be found in literature, just few studies addressing the profile of their consumers were carried out. Thus, this study evaluated firmness and biochemical composition of Shitake and Shimeji marketed in natura, and the profile and preference of consumers, aiming at directing the fungiculture production chain.

\section{MATERIAL AND METHODS}

\section{Samples}

This study was carried out in two stages: the first consisted of analyzing firmness and biochemical traits of Shitake and Shimeji commercialized in natura, and the second stage was an opinion survey which was carried out with mushroom consumers.

In natura mushrooms, Shitake and Shimeji, were bought at supermarkets in the city of Londrina-PR, commercialized in 200-g trays, covered by transparent plastic film and stored at $10^{\circ} \mathrm{C}$. The samples consisted of five trays of each kind of mushroom, selected from simple random sampling. To perform the analysis, the samples were kept under refrigeration $\left(8^{\circ} \mathrm{C}\right)$ for up to three days and, for each kind of mushroom, all trays were mixed to obtain a compost sample.

\section{Firmness}

Firmness was expressed in $\mathrm{N}$ and measured according to Arazuri et al. (2007), using a bench texturometer (Model TA.XT Plus, Stable Micro System, The United Kingdom) from the compressive strength of the cap (upper part of the basidiomycete), applying a 35 $\mathrm{mm}$ diameter aluminum probe at $0.5 \mathrm{~mm}$ $\mathrm{s}^{-1}$ speed. Firmness mean was obtained using the analysis of ten mushrooms.

\section{Protein and lipid contents}

Crude protein content was quantified by nitrogen distillation (Kjeldahl method), corrected using a factor of 4.38 and, to quantify lipids, Soxhlet extraction method (AOAC, 2012) was used. Both attributes were expressed in $\%(\mathrm{~m} / \mathrm{m})$, using ten replicates for each mushroom.

Bioactive compounds and antioxidant activity

To quantify total phenolic compounds, flavonoids and antioxidation activity, a suspension was prepared using $1.00 \mathrm{~g}$ of fresh samples with $10.0 \mathrm{~mL}$ ethanol at $70 \%(\mathrm{v} / \mathrm{v})$, under agitation for $30 \mathrm{~min}$. Afterwards, the samples were centrifuged at $1013 \mathrm{x} \mathrm{g}$ (Excelsa 2 Fanem modelo 205N) for 5 minutes and supernatant was separated for analysis (Vázquez et al., 2008).

Content of phenolic compounds was quantified through spectrophotometric method using the Folin-Ciocalteu reagent. Gallic acid was adopted as the analytical standard and readings were taken spectrophotometrically at 765 $\mathrm{nm}$. The mean of the five replicates was expressed in mg equivalent of gallic acid equivalents per $100 \mathrm{~g}$ of sample (Swain
\& Hillis, 1959).

For quantifying the total flavonoids, ethanolic extract was mixed with a 5.0\% aluminum chloride solution in a basic medium, reading at $425 \mathrm{~nm}$. Quercetin was used as analytical standard and the mean of five replicates was expressed in $\mathrm{mg}$ of quercetin equivalents $(\mathrm{QE}) / 100$ $\mathrm{g}$ of the sample (Gurnani et al., 2016).

To determine antioxidant activity, we used 2.2-diphenyl-1-picryl-hydrazyl radical scavenging $(\mathrm{DPPH} \bullet$ ) adapted from Brand-Williams et al. (1995). Absorbance was recorded at $517 \mathrm{~nm}$ and analytical curve was performed using Trolox (6-hydroxy-2,5,7,8tetramethylchroman-2-carboxylic acid) as standard. The mean of five replicates was expressed in \% free radical scavenging. Additionally, FRAP assay (Benzie \& Strain, 1996) was also applied to determine extract reducing power, with reading at $517 \mathrm{~nm}$. The mean of the five replicates was expressed as $\mu$ mol of trolox equivalent antioxidant capacity (TEAC)/100 g of sample.

\section{Profile and preference of} consumers

Opinion survey to verify the preference and profile of mushroom consumers consisted of an online questionnaire, using the Google Form tool, which required adherence to the Informed Consent Form. The questionnaire link was posted on social media to reach as many people as possible from different parts of Brazil. The individuals who participated are mushroom consumers over the age of 17: being the criteria used for recruitment. The research was approved by the Ethics Committee for Research Involving Human Beings at UEL, under No. 13651019.0.0000.5231.

The survey included 20 questions, of which nine were related to consumers' profile and 11 to consumers' preferences (Appendix). The questions were about: region of the country where the consumer lived, sex, age, profession, education level, monthly income, consumption frequency, choice criteria, consumed species, place of purchase, preference in relation to Shitake and Shimeji, traits which they like the most, the least pleasing trait, the way in which the mushroom is acquired, the form of 
consumption, the purpose of use and the factor which would make the consumer eat more of the product.

\section{Statistical analysis}

The means of the biochemical characterization of the mushrooms were compared through $\mathrm{t}$ test $(p<0.05)$, using $\mathrm{R}$ software. Participant profiles were plotted in graphs, and the consumers' preference submitted to Qui-squared test $(p<0.05)$.

\section{RESULTS AND DISCUSSION}

\section{Biochemical composition}

The highest contents of phenolic compounds, flavonoids, antioxidant activity and lipids were found in Shitake mushrooms, whereas the protein content did not differ for both mushrooms (Table 1). The variation found for the evaluated traits can be attributed to the differences in growing conditions, fact which was not investigated in this study, as well as the intrinsic genetic traits of each species.

Shitake showed four times higher compression strength comparing with Shimeji (Table 1), which can be associated with a greater amount of pectin, cellulose and hemicellulose present in Shitake cell wall, since these structural components are related to the mechanical resistance and tissue cohesiveness (Zhongdong et al., 2006). Firmness is directly related to the mushroom texture, implying its sensory acceptability and form of preparation for consumption.

Another fact which can influence on a greater firmness of Shitake, is a larger fruiting body compared to Shimeji. This relationship was already observed in cherry tomatoes: larger fruits showed higher firmness when comparing with medium and small-sized fruits (Islam $e t$ al., 2019). Li et al. (2017) observed that the fungus Volvariella volvacea showed firmness of $2.71 \mathrm{~N}$ and the largest fruiting body among the evaluated mushrooms.

In Table 1, we noticed that the content of total phenolic compounds in Shitake mushroom was approximately four times higher than in Shimeji. Lower contents of total phenolic compounds in
Shimeji comparing with other species of macrofungi were also reported in literature. Palacios et al. (2011) reported that the mushroom species Calocybe gambosa, Cantharellus cibarius, Craterellus cornucopioides, Hygrophorus marzuolus, Lactarius deliciosus and Pleurotus ostreatus contain lower levels of phenolic compounds and they also mentioned that the species Boletus edulis has almost three times more phenolic compounds than Shimeji, and Agaricus bisporus two times more.

Boonsong et al. (2016) found a mean of $24.25 \pm 0.49$ for phenolic compounds in Shitake (Lentinus edodes), low value comparing with the one found in this study. Gaitán-Hernández et al. (2020) proved that the fungus strain and the substrate significantly interfere in the content of this attribute, reporting values from 1.59 to $2.71 \mathrm{mg} 100 \mathrm{~g} \mathrm{~g}^{-1}$ of fresh Shitake, using as substrate vineyard pruning, sorghum stubble, sugarcane bagasse and oak.

Contents of phenolic compounds and antioxidant activity in mushroom cap can be reduced at temperatures above $25.55^{\circ} \mathrm{C}$ and in relation to the exposure time (Liaotrakoon \& Liaotrakoon, 2018). Shitake mushrooms grow at low temperatures, from 15 to $20^{\circ} \mathrm{C}$ (Maki et al., 2001), whereas Shimeji mushrooms grow at moderate temperatures, which range from 18 to $30^{\circ} \mathrm{C}$ (Jaramillo et al., 2013), which can explain the lowest contents of phenolic compounds found in Shimeji in this study.

High contents of total phenolic compounds are desirable, since they are natural antioxidants and have several therapeutic properties, such as inhibition of lipid peroxidation, antimicrobial activity, tumor activities, chemopreventive and antiinflammatory activities (Tanase et al., 2014; Muszyńska et al., 2018). Greater antioxidant activities of Shitake were also observed, double the capacity to capture free radicals $(75.51 \%)$ when compared with Shimeji (34.89\%). Shitake's antioxidant activity is superior to that of common foods in Brazilian diet, such as snap beans and kale (Rigueira et al., 2016; Fukuji et al., 2019).

Antioxidant activity involves the interaction of different components in food, because it depends on the concentration and action of carotenoids, vitamin $C$, vitamin $\mathrm{E}$ and phenolic compounds. Thus, the different concentrations and composition of antioxidants could clarify the difference found in the contents of antioxidant activities of Shitake and Shimeji (Table 1), since in 100 grams of Shitake, 2.1 $\mathrm{mg}$ of vitamin $\mathrm{C}$ can be found, whereas $1.6 \mathrm{mg}$ can be found in Shimeji (Mattila et al., 2001).

Crude protein content was the only biochemical attribute which did not differ significantly among mushrooms (Table 1), showing that both are interesting for people who adopt a high-protein diet. However, Andrade et al. (2008) reported that the crude protein contents, as well as the ether extract, ash and Shitake fibers differed from the other evaluated mushrooms, justified by the effect of the macrofungus

Table 1. Mean ( \pm standard deviation) of firmness and biochemical attributes of Shitake and Shimeji mushrooms. Londrina, UEL, 2020.

\begin{tabular}{|c|c|c|}
\hline \multirow{2}{*}{ Attribute } & \multicolumn{2}{|c|}{ Mushroom } \\
\hline & Shimeji & Shitake \\
\hline Firmness $(\mathrm{N})$ & $1.44 \pm 0.32$ & $5.52 \pm 0.27 *$ \\
\hline $\begin{array}{l}\text { Content of total phenolic compounds (mg } 100 \\
\mathrm{~g}^{-1} \text { ) }\end{array}$ & $34.73 \pm 5.07$ & $193.80 \pm 12.16^{*}$ \\
\hline Content of total flavonoids $\left(\mathrm{mg} 100 \mathrm{~g}^{-1}\right)$ & $109.90 \pm 6.70$ & $271.0 \pm 14.88^{*}$ \\
\hline Antioxidation activity - DPPH (\%) & $34.89 \pm 1.72$ & $75.51 \pm 2.13^{*}$ \\
\hline Antioxidation activity - FRAP $\left(\mu \mathrm{mol} 100 \mathrm{~g}^{-1}\right)$ & $12.48 \pm 1.62$ & $152.40 \pm 19.81^{*}$ \\
\hline Crude protein content $(\%)$ & $26.64 \pm 0.56$ & $27.09 \pm 3.23$ \\
\hline Ethereal extract content - lipids (\%) & $0.47 \pm 0.08$ & $1.26 \pm 0.04 *$ \\
\hline
\end{tabular}

Mean followed by asterisk is significantly higher by t-Student test $(\mathrm{P}<0.05)$. 
lineage interaction with the eucalyptus substrate. Furlani \& Godoy (2007) reported that differences in biochemical compounds of the mushrooms may show differences among the evaluated lots of the same species, showing that the differences are related to the region where the macrofungus was cultivated and the substrate used in this cultivation.

Carbon and nitrogen ratio $(\mathrm{C} / \mathrm{N})$ of the substrate is an important fact, which can determine the protein content in mushrooms. This is due to the fact that these macrofungi have a high rate of assimilation of this nitrogen (Ghosal et al., 2016). Thus, substrates with low $\mathrm{C} / \mathrm{N}$ ratio are preferably indicated to increase the nitrogen content in edible mushrooms (Ajonina \& Tatah, 2012). That is the reason why, studies on the chemical composition of substrates for growing mushrooms, relating to readily available forms of nitrogen, are relevant.

The low lipid content is another prominent factor for mushrooms, even though a significant difference for this attribute was noticed (Table 1). Shitake showed almost three times the mean lipid content $(1.26 \%)$, comparing with Shimeji $(0.47 \%)$. According to Furlani \& Godoy (2007), Shitake has higher lipid content $(4.39 \%)$ compared with Shimeji $(4.30 \%)$, although the contents of both are lower than that of the
Champignon (5.42\%).

\section{Market survey of mushroom consumers}

A total of 308 individuals participated in the survey, the majority being women $(64 \%)$ living in the Southern region of Brazil. The authors noticed that $64 \%$ of the consumers are young and adults up to 35 years old, with high scholar degree (64\% with complete higher education). We highlight that mainly young and adult Brazilians are concerned about a healthy eating habit, in addition to confirming that people with a higher level of education opt for healthier food choices (Finger et al., 2013). Also, thirty nine people, working in the food sector,

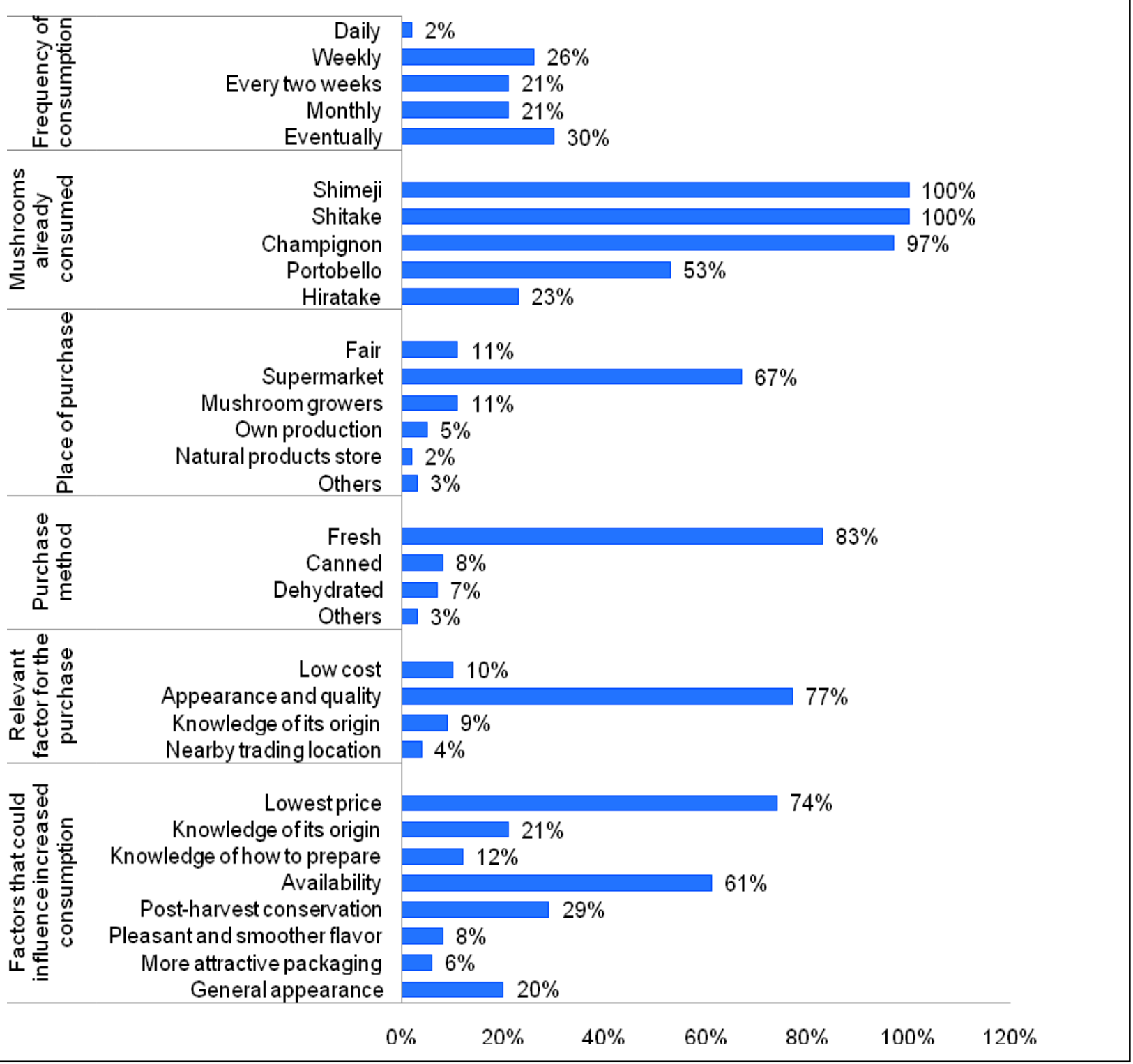

Figure 1. Factors related to purchasing and consuming of mushrooms. Londrina, UEL, 2020. 
and three fungi farmers took part in the survey. These people form an important group for this evaluation since they are directly related to the market and production chain, respectively. Among these participants, $40 \%$ reported a monthly income of 4 or more minimum salaries, similar to the US scenario where most consumers have an income of more than $\$ 100,000$ per year (Fresh
Trends, 2020).

A third of participants reported that they consume mushrooms weekly and a minority of them reported consuming mushrooms daily (Figure 1). The frequency of mushroom consumption by Brazilians is similar to that found in other countries, such as China (Wen et al., 2016) and Portugal (Boin \& Nunes, 2018), mostly weekly. This regular frequency can be justified by the awareness of the health benefits of mushrooms and the increase in Brazilian income since the 1990s (Royse, 2014).

Boin \& Nunes (2018) also reported that the frequency in mushroom consumption is influenced by the educational level, gender and family size, considering that the gender and size of the family have a negative effect

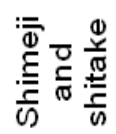 \\ Shimeji and shitake}

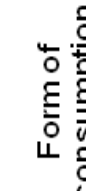

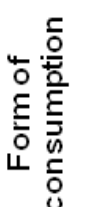

Salad
Others

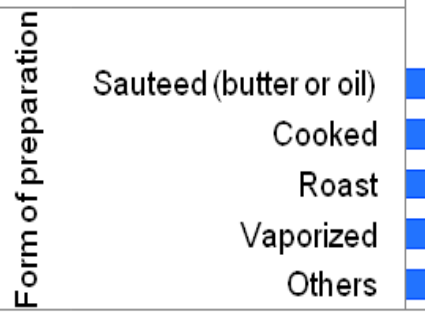

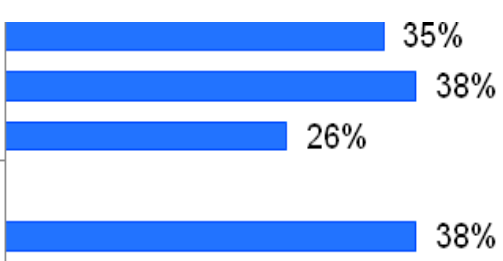

$38 \%$

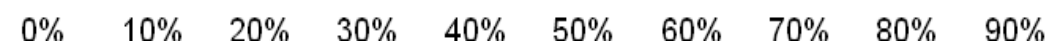

Figure 2. Consumers' preference in relation to form of consumption and preparation of Shitake and Shimeji mushrooms. Londrina, UEL, 2020.

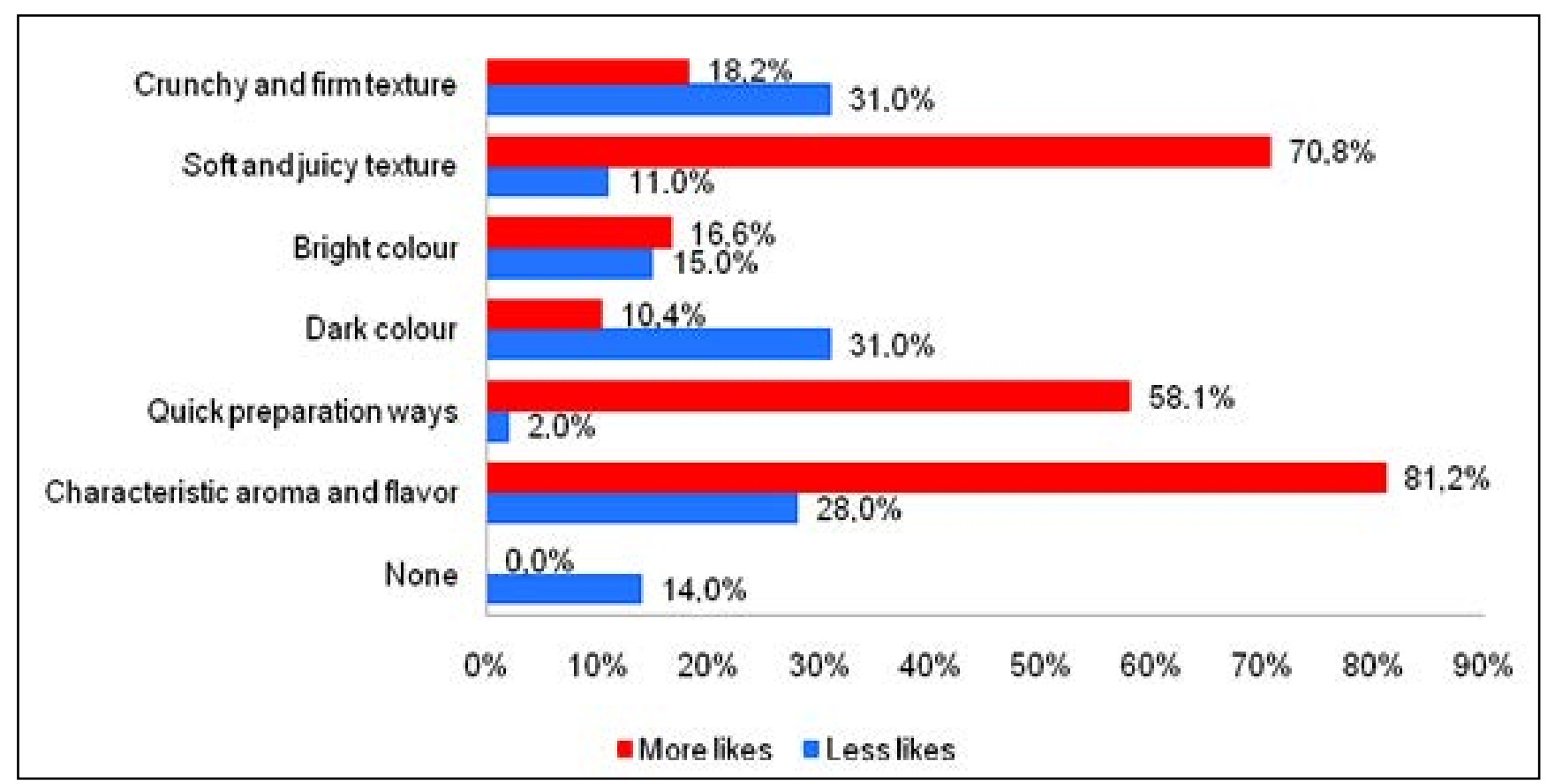

Figure 3. Sensory attributes that impact consumers' preference for Shitake and Shimeji. Londrina, UEL, 2020. 
on the frequency of consumption, while the level of education has a positive effect. Men from families with more than four people tend to consume less mushrooms, whereas consumers with higher education levels and smaller families consume mushrooms more often.

According to the reports, the most consumed mushrooms are Shitake, Shimeji, Champignon and Portobello (Figure 1), whereas Hiratake is the least consumed mushroom. These results are similar to the ones found for worldwide consumption, and showed that the most consumed species are the ones belonging to the genera Lentinula spp., Pleurotus spp., Auricularia spp. and Agaricus spp., 22\%, 19\%, 18\% and 15\% at worldwide level, respectively (Royse et al., 2017).

The consumers generally buy mushrooms at the supermarket, according to the Brazilian participants. In Turkey, the product is also purchased mainly at the supermarket, due to a greater consumers' confidence in this type of establishment (Gürgen et al., 2018).

According to the participants, the most influential factor for purchase decision is appearance and quality of the mushroom, whereas the factors which most limit consumption are lack of the product availability and supply in the market throughout the year, in addition to the high perishability and price (Figure 1). According to Gonçalves et al. (2017), the low intention to purchase Hiratake mushroom is due to its high price. These authors verified that only $26 \%$ of the participants reported that they would buy mushroom, whereas $51.2 \%$ considered this product acceptable.

No significant difference was verified using the Qui-squared test $(\mathrm{p}<0.05)$, considering the preference for one of the mushrooms evaluated in this study (Figure 2). Morevoer, 26\% of them responded that they like both the same. Consumption preference considering some mushroom species depends on the evaluated public and country, since the studies which were carried out in India reported that white bud (Agaricus bisporus) is the most consumed macrofungus (Shirur et al., 2014), whereas the oyster mushroom (Pleurotus spp.) is the most popular in Ghana (Kortei et al., 2018).

Sautéed mushrooms in butter, olive oil or oil are the most popular form of preparation reported by participants (Figure 2). As for consumption, most participants $(53 \%)$ prefer mushrooms as meal accompaniment, and the second form as a main dish (38\%). This eating habit is similar to the one of American people, $75 \%$ use the mushrooms as ingredients in dishes and $37 \%$ as the main dish for meals (Fresh Trends, 2020).

The determinant attributes for purchasing Shitake and Shimeji are flavor and aroma (Figure 3). The consumers also reported that they buy the product according to texture, soft and juicy, and if they are good ingredients for a quick-made dish. These results show that Brazilians have criteria which are different from Indians when it comes to mushrooms, since Shirur et al. (2014) verified that the main criterion when choosing mushrooms in India is the color, according to almost half of the interviewed consumers, whereas size and shape were the main attributes for only about $28 \%$ of the interviewed consumers.

The least popular attributes of mushrooms, considered by Brazilian consumers, were crispy and firm texture, darker color, aroma and flavor. Flavor is not the main factor determining purchasing, which differs from the other Asian countries, such as Malaysia, where the mushroom-based products are consumed due to its flavor (Amin et al., 2017). The difference in relation to more determining attributes when purchasing mushrooms can be attributed to cultural factor, since the Asian countries consume more (per capita consumption) mushrooms than American countries (Royse et al., 2017).

Cabrera et al. (2020) observed that the low mushroom production in Parana is related to the lack of technology orientation for this sector, high input prices of other states and mushroom price competition in São Paulo. Fungi farmers are very concerned with the production and marketing chain of fresh mushrooms, in order to ensure longer shelf life. Nevertheless, in Brazil no updated information on volume and distribution of mushrooms as well as the main forms of commercialization (fresh, dehydrated and preserved) can be found. This fact greatly affects the decision-making in relation to the national fungiculture production chain.

No difference was observed between Shitake and Shimeji (Figure 3), even considering that the firmer texture and darker color of Shitake is not appreciated by most consumers. Thus, Shitake is as important as Shimeji for the Brazilian market. Nevertheless, to meet the consumers' demand, investment on researches and technical assistance for the sector is necessary, for longer shelf life, production cost optimization and formal organization of the production chain.

\section{REFERENCES}

AJONINA, AS; TATAH, LE. 2012. Growth performance and yield of oyster mushroom (Pleurotus ostreatus) on different substrates composition in Buea South West Cameroon. Science Journal of Biochemistry, 2012: 16.

ALVES, M; FERREIRA, ICFF; DIAS, J; TEIXEIRA, V; MARTINS, A; PINTADO, M. 2012. A review on antimicrobial activity of mushroom (Basidiomycetes) extracts and isolated compounds. Planta Medica 78: 1707-1718.

AMIN, MZM; HARUN, A; WAHAB, MAMA; RAHIM, H; HAIMID, MT. 2017. A Study of consumer behaviour towards mushroombased products in Malaysia. Economic and Technology Management Review 12: 55-63.

ANDRADE, MCN; MINHONI, MTA; ZIED, DC. 2008. Avaliação nutricional do cogumelo Shitake [Lentinula edodes (Berk.) Pegler] em função da linhagem e do tipo de eucalipto cultivado. Ciência e Tecnologia de Alimentos, 28: 916-921.

ANPC. 2019. Associação Nacional dos Produtores de Cogumelos. Available at: URL/https://www. anpccogumelos.org/cogumelos. Accessed October 10, 2020.

AOAC. 2012. Official methods of analysis of the association of official analytical chemistry. Washington, USA: The Association. 5p.

APTA. 2019. Agência Paulista de Tecnologia dos Agronegócios. Available at: URL/https://www. apta.sp.gov.br/. Accessed October 10, 2020.

ARAZURI, S; JARÉN, C; ARANA, JI; CIRIZA, JJP. 2007. Influence of mechanical harvest on the physical properties of processing tomato (Lycopersicon esculentum Mill.). Journal of Food Engineering 80: 90-198.

BENZIE, IFF; STRAIN, JJ. 1996. The ferric 
reducing ability of plasma (FRAP) as a measure of "antioxidant power": The FRAP Assay. Analytical Biochemistry, 239: 70-76.

BOIN, E; NUNES, J. 2018. Mushroom consumption behavior and influencing factors in a sample of the Portuguese population. Journal of International Food e Agribusiness Marketing 30: 35-48.

BOONSONG, S; KLAYPRADIT, W; WILAIPUN, P. 2016. Antioxidant activities of extracts from five edible mushrooms using different extractants. Agriculture and Natural Resources 50: 89-97.

BRAND-WILLIAMS, W; CUVELIER, ME; BERSET, C. 1995. Use of a free radical method to evaluate antioxidant activity. $L W T$, 28: 25-30.

CABRERA, LC; CONSTANTINO, LV; ANTUNES, OS; GONÇALVES, LSA; CORTE, LED. 2020. Caracterização da produção de cogumelos comestíveis: estudo de caso na região de Londrina, Paraná. Research, Society and Development 9: 1-14.

CHUN, S; CHAMBERS, E; HAN, I. 2020. Development of a sensory flavor lexicon for mushrooms and subsequent characterization of fresh and dried mushrooms. Foods, 9: 1-16.

FINGER, JD; TYLLESKÄR, T; LAMPERT, T; MENSINK, GBM. 2013. Dietary behaviour and socioeconomic position: the role of physical activity patterns. PLOS ONE 8: 1-10.

FINIMUNDY, TC; GAMBATO, G; FONTANA, R; CAMASSOLA, M; SALVADOR, M; MOURA, S; HESS, J; HENRIQUES, JAP, DILLON, AJP, ROESCH-ELY, M. 2013. Aqueous extracts of Lentinula Edodes and Pleurotus Sajor-Caju exhibit high antioxidant capability and promising in vitro antitumor activity. Nutrition Research 33: 76-84.

FRESH TRENDS. 2020. The Packer. Available at: URL/https://www.thepacker.com/FreshTrends-Data. Accessed October 10, 2020.

FUKUJI, AYS; CONSTANTINO, LV; ZEFFA, DM; ANDRADE, FA; SILVA, MB; GONÇALVES, LSA. 2019. Amino acid concentration, total phenolic compound content and antioxidant activity of snap bean genotypes. Brazilian Journal of Food Technology 22: 1-6.

FURLANI, RPZ; GODOY, HT. 2007. Valor nutricional de cogumelos comestíveis. Ciência e Tecnologia de Alimentos 27: 154-157.

GAITÁN-HERNÁNDEZ, R; AQUINOBOLAÑOS, EN; HERRERA, M; SALMONES, D. 2020. Yield, and phenolic content of Shitake mushrooms cultivated on alternative substrates. Emirates Journal of Food and Agriculture 32: 188-197.

GHOSAL, D; GHOSH, S; DUTTA, TD; AHN, Y. 2016. Current state of knowledge in microbial degradation of polycyclic aromatic hydrocarbons (PAHs): A review. Frontiers in Microbiology, 7: 1-27

GONÇALVES, AOS; DAVID, GQ; SILVA, MP; PERES, WM; YAMASHITA, OM. 2017. Avaliação sensorial e aceitação comercial do cogumelo comestível Pleurotus florida. Journal of Neotropical Agriculture 4: 92-98.
GÜRGEN, A; YILDIZ, S; YILDIZ, ÜC. 2018. Determination of mushroom consumption preferences by using fuzzy analytic hierarchy process, Eurasian Journal of Forest Science 6: 25-34.

GURNANI, N; GUPTA, M; MEHTA, D; MEHTA, BK. 2016. Chemical composition, total phenolic and flavonoid contents, and in vitro antimicrobial and antioxidant activities of crude extracts from red chilli seeds (Capsicum frutescens L.). Journal of Taibah University for Science, 10: 462-470.

ISLAM, ZM; LEE, YT; MELE, MA; CHOI, IL; KANG, HM. 2019. Effect of fruit size on fruit quality, shelf life and microbial activity in cherry tomatoes. AIMS Agriculture and Food 4: $340-348$.

JARAMILLO, SM; ALBERTÓ, E. 2013. Heat treatment of wheat straw by immersion in hot water decreases mushroom yield in Pleurotus Ostreatus. Revista Iberoamericana de Micología, 30: 125-129.

KORTEI, NK; ODAMTTEN, GT; OBODAI, M; WIAFEKWAGYAN, M; PREMPEH, J. 2018. Survey of mushroom consumption and the possible use of gamma irradiation for sterilization of compost for its cultivation in Southern Ghana. Agriculture and Food Security 7: 1-7.

LI, N; CHEN, F; CUI, F; SUN, W; ZHANG, J; QIAN, L; YANG, Y; WU, D; DONG, Y; JIANG, J; YANG, H. 2017. Improved postharvest quality and respiratory activity of straw mushroom (Volvariella Volvacea) with ultrasound treatment and controlled relative humidity. Scientia Horticulturae 225: 56-64.

LIAOTRAKOON, W; LIAOTRAKOON, V. 2018. Influence of drying process on total phenolics, antioxidative activity and selected physical properties of edible bolete (Phlebopus colossus (R. Heim) Singer) and changes during storage. Food Science and Technology, 38: 231-237.

MAKI, CS; TEIXEIRA, FF; PAIVA, E; MEIRELLES, LDP. 2001. Analyses of genetic variability in Lentinula edodes through mycelia responses to different abiotic conditions and RAPD molecular markers. Brazilian Journal of Microbiology, 32: 170-175.

MATTILA, P; KÖNKÖ, K; EUROLA, M; PIHLAVA, JM; ASTOLA, J; VAHTERISTO, L; HIETANIEMI, V; KUMPULAINEN, J; VALTONEN, M; PIIRONEN, V. 2001. Contents of vitamins, mineral elements, and phenolic compounds in cultivated mushrooms. Journal of Agricultural and Food Chemistry 49: 2343-2348.

M U S Z Y Ń S K A , B ; G R Z Y W A C Z KISIELEWSKA, A; KAŁA, K; GDULAARGASIŃSKA, J. 2018. Anti-inflammatory properties of edible mushrooms: a review. Food Chemistry 243: 373-381.

PALACIOS, I; LOZANO, M; MORO, M; ARRIGO, AD; ROSTAGNO, MA; MARTÍNEZ, JÁ; LAFUENTE, AG; GUILLAMÓN, E; VILLARES, A. 2011. Antioxidant properties of phenolic compounds occurring in edible mushrooms. Food Chemistry 128: 674-678.

PAULA, DP; TARSITANO, MAA; GRACIOLLI,
LA. 2001. Viabilidade econômica do cultivo de Shitake em diferentes escalas de produção. Scientia Agricola, 58: 431-436.

RAHMAN, MA; ABDULLAH, N; AMINUDIN, N. 2018. Lentinula edodes (Shitake mushroom): an assessment of in vitro antiatherosclerotic bio-functionality. Saudi Journal of Biological Sciences 25: 1515-1523.

RIGUEIRA, GDJ; BANDEIRA, AVM; CHAGAS, CGO; MILAGRES, RCRM. 2016. Atividade antioxidante e teor de fenólicos em couvemanteiga (Brassica Oleracea l. var. acephala) submetida a diferentes sistemas de cultivo e métodos de preparo. Semina: Ciências Biológicas e da Saúde 37: 3-12.

ROYSE, DJ. 2014. A global perspective on the high five: Agaricus, pleurotus, Lentinula, auricularia Eflammulina. In: PROCEEDINGS OF THE $8^{\text {th }}$ INTERNATIONAL CONFERENCE ON MUSHROOM BIOLOGY AND MUSHROOM PRODUCTS (ICMBMP8), 18. Resumos... New Delhi, India: ABH. (CD-ROM).

ROYSE, DJ; BAARS, J; TAN, Q. 2017. Current overview of mushroom production in the world. in: CUNHA, ZD; PARDO-GIMÉNEZ, A (eds). Edible and Medicinal Mushrooms: Techonology and Applications. p. 5-13.

SHIRUR, M; AHLAWAT, OP; MANIKANDAN, K. 2014. Mushroom consumption and purchasing behaviour in India: a study among selected respondents. Mushroom Research 23: 225-231.

SWAIN, T; HILLIS, WE. 1959. The phenolic constituents of Prunus domestica. I. The quantitative analysis of phenolic constituents. Journal of the Science of Food and Agriculture, 10: 63-68.

TANASE, C; BOZ, I; STINGU, A; VOLF, A; POPA, VI. 2014. Physiological and biochemical responses induced by spruce bark aqueous extract and deuterium depleted water with synergistic action in sunflower (Helianthus Annuus L.) plants. Industrial Crops and Products 60: 160-167.

VALVERDE, ME; PÉREZ, TH; LÓPEZ, OP. 2014. Edible mushrooms: improving human health and promoting quality life. International Journal of Microbiology 2015: 1-15.

VÁZQUEZ, G; FONTENLA, E; SANTOS, J; FREIRE, MS; ÁLVAREZ G; ANTORRENA, G. 2008. Antioxidant activity and phenolic content of chestnut (Castanea sativa) shell and eucalyptus (Eucalyptus globulus) bark extracts. Industrial Crops and Products, 28 : 279-285.

WEN Q; LU, J; CAI, X; YANG, S; ZHANG, C. 2016. Research on consumer behavior of edible mushroom and its influencing factors: based on spot investigation in Beijing. Advances in Social Sciences 5: 442-451.

YU, S; WEAVER, V; MARTIN, K; CANTORNA, MT. 2009. The effects of whole mushrooms during inflammation. BMC Immunology 10 : $1-13$.

ZHONGDONG, L; GUOHUA, W; YUNCHANG, G; KENNEDY, JF. 2006. Image study of pectin extraction from orange skin assisted by microwave. Carbohydrate Polymers, 64 : 548-552. 